\title{
Peluang Peran Serta Para Ahli Hukum Islam di Indonesia dalam Perumusan Kebijakan Publik
}

\author{
Erik Darmawan \\ Fakultas Ilmu Sosial dan Ilmu Politik Universitas Islam Negeri Raden Fatah Palembang \\ Email: erik_yasri@yahoo.co.id
}

\begin{abstract}
Indonesia is a predominantly Muslim country. Muslims have their own rules of life, needs and interests that must be met that are different from other community groups. With its existence, the Indonesian Muslims are a group of interests. In the context of the life of the state, the needs and interests of Muslims can be fulfilled legally formal through their active participation in the political process and the process of public policy formulation. This paper examines the opportunities that Islamic jurists can take in the process of public policy formulation so that the needs and interests of Muslims can be met. The trick is to formulate new laws based on actual Islamic values, based on problems and realities in society and then propose them into a public policy. Islamic jurists must also actively engage in the process of public policy formulation. That is an opportunity that Muslim jurists can gain in helping people meet their distinctive needs and interests.
\end{abstract}

Keywords: opportunities, participation, islamic jurists, public policy

\begin{abstract}
Abstrak
Indonesia adalah negara berpenduduk mayoritas muslim. Umat Islam memiliki aturan hidup, kebutuhan dan kepentingan tersendiri yang harus dipenuhi yang berbeda dengan kelompok masyarakat lainnya. Dengan eksistensinya itu umat Islam Indonesia adalah sebuah kelompok kepentingan. Dalam konteks kehidupan bernegara, kebutuhan dan kepentingan umat Islam dapat terpenuhi secara legal formal lewat peran serta mereka secara aktif dalam proses politik dan proses perumusan kebijakan publik. Tulisan ini mengkaji peluang yang dapat diambil oleh para ahli hukum Islam dalam proses perumusan kebijakan publik sehingga kebutuhan dan kepentingan umat Islam dapat dipenuhi. Caranya adalah dengan merumuskan hukum-hukum baru yang berlandaskan nilai-nilai Islam, yang actual dan didasarkan pada problem dan realitas di masyarakat kemudian mengusulkannya menjadi sebuah kebijakan publik. Peluang yang dapat diraih oleh para ahli hukum Islam dalam membantu umat memenuhi kebutuhan dan kepentingannya yang khas.
\end{abstract}

Kata kunci : peluang, partisipasi, hukum islam, kebijakan publik 


\section{PENDAHULUAN}

Dalam konteks kehidupan bernegara, politik bagaikan mata air yang kemudian melahirkan sungaisungai. Dari sungai-sungai itu semua pihak memenuhi berbagai kebutuhannya. Dalam realitas, politik adalah sebuah proses awal tempat semua urusan bermula. Politik melahirkan kekuasaan, kekuasaan melahirkan aturan, aturan melahirkan kebijakan publik yang merupakan standar bagi segala urusan hidup dan mati seluruh warga negara. Kebijakan publik melahirkan harga-harga seluruh barang kebutuhan hidup, urusan kesehatan, pendidikan, perumahan, keamanan, peribadatan, jalan, jembatan, nilai mata uang, bunga pinjaman, impor dan ekspor dan sebagainya.

Singkatnya, politik melalui produknya yaitu kebijakan publik adalah sumber hidup dan mati seluruh warga negara. Jika kebijakan publik dibuat sesuai kebutuhan warga negara maka seluruh warga negara dapat hidup berbahagia. Namun jika kebijakan publik dibuat hanya untuk kepentingan sekelompok orang maka kebijakan itu akan menjadi alat penyengsara bagi kebanyakan warga negara dan menjadi kebahagiaan bagi segelintir manusia saja. Demikian pentingnya politik dan kebijakan publik, dua hal ini merupakan proses vital yang tidak boleh diabaikan oleh seluruh warga negara khususnya kelompok-kelompok kepentingan.

Indonesia adalah negara yang mayoritas penduduknya beragama Islam. Umat Islam Indonesia dapat dikatakan sebagai suatu kelompok kepentingan. Karena mereka memiliki aturan hidup, kebutuhan dan kepentingan tersendiri yang harus dipenuhi. Aturan hidup, kebutuhan dan kepentingan meeka berbeda dengan kelompok-kelompok lainnya. Kebutuhan dan kepentingan umat Islam tesebut tentunya harus terpenuhi agar mereka bisa hidup sesuai aturan agama yang mereka yakini.

Dalam konteks kehidupan bernegara, kebutuhan dan kepentingan umat Islam dapat terpenuhi secara legal lewat peran serta mereka secara aktif dalam proses politik dan proses perumusan kebijakan publik. Dengan demikian "rumus" yang berlaku adalah "jika umat Islam ingin meningkatkan pemenuhan kebutuhan dan kepentingan hidupnya maka mereka harus meningkatkan peran aktif mereka dalam proses politik dan proses perumusan kebijakan publik."

Namun realitas menunjukkan hal sebaliknya. Sebagian para ahli hukum Islam, sebagai bagian penting dari umat Islam, menganggap politik adalah sesuatu yang kotor dan harus dijauhi. Sebagian lainnya sangat menginginkan ajaran Islam dapat diwujudkan menjadi peraturan perundang-undangan ataupun juga kebijakan publik namun dengan cara memaksakan teks-teks syariah (al-Qur'an dan al- Hadits) dimasukkan ke dalam peraturan perundang-undangan atau pun juga kebijakan publik. Pola seperti ini pada akhirnya hanya menimbulkan penolakan dan antipati dai semua pihak termasuk umat Islam sendiri dengan alasan "negara ini bukan agama".

Persoalan ini adalah masalah terbesar yang dihadapi oleh umat Islam Indonesia. Di satu sisi, sebagai muslim mereka wajib melaksanakan syariah, namun di sisi lain sebagai warga negara Indonesia, mereka wajib mentaati peratuan perundang-undangan dan produk turunannya yaitu kebijakan publik, yang saat ini sangat minim dalam mengakomodasi syariah. Persoalan ini belum kunjung menemukan solusinya, sehingga penulis sangat menarik untuk mengkajinya dalam makalah ini. 
Dari apa yang telah dikemukakan pada bagian latar belakang di atas, dapat ditarik sebuah pokok persoalan yaitu bagaimana cara mewujudkan syariah menjadi kebijakan publik di Indonesia. Dari pokok persoalan tersebut maka penulis merumuskan sebuah permasalahan yaitu "bagaimanakah peluang peran yang dapat dilakukan oleh para ahli hukum Islam di Indonesia dalam mewujudkan syari'ah menjadi kebijakan publik".

Tinjauan ini bertujuan untuk mengembangkan kesadaran bahwa agama Islam atau syariah bukanlah sekedar nilai normatif belaka yang secara final hanya berbicara mengenai halal-haram, pahala-dosa, alam kubur-hari kiamat dan surga-neraka. Bersamaan dengan sisi normatifnya, Islam adalah juga agama aplikatif-progressif-responsif. Islam berbicara tentang kehidupan dunia dalam berbagai aspeknya, memberikan landasan norma pada setiap zaman untuk diaplikasikan sebagai kemampuan responsif dan progressif agama Islam. Bagaimana cara syariah dapat diaplikasikan dalam realitas adalah tugas semua pihak, khususnya mereka yang memiliki tanggung jawab dalam merumuskan dasar-dasar normatif bagi aplikasi syariah dalam kehidupan sehari-hari yaitu para Ahli Hukum Islam.

Dalam konteks kehidupan bernegara, jalur legal untuk mengaplikasikan nilai-nilai keyakinan kedalam kehidupan sehai hai adalah melalui produk politik yaitu kebijakan publik. Tinjauan ini bermanfaat untuk memberikan informasi bahwa seunggul apapun agama Islam, ia bisa kehilangan fungsi, bahkan mengalami kematian, jika ia kehilangan kemampuan aplikatif dan kehilangan kemampuan merespon segala dinamika yang terjadi di masyarakat. Tinjauan inipun memberikan informasi bahwa kebijakan publik adalah sarana utama yang dapat dijadikan saluran untuk mengaplikasikan nilai-nilai syariah dalam kehidupan berbangsa dan benegara secara legal dan dapat diterima semua pihak.

\section{METODE PENELITIAN}

Tulisan ini merupakan hasil kajian mendalam terhadap beberapa literatur yang memiliki signifikansi dengan topik kajian ini. Hal pertama yang dilakukan adalah melakukan inventarisasi terhadap beberapa unsur yang terhubung, kemudian melakukan pembacaan dan analisis. Selanjutnya dilakukan penelaahan dan penulisan terhadap aspek yang dikaji. Analisis terhadap naskah dilakukan dengan melihat dan mencermati berbagai isu dan aspek terkait dan kemudian menghubungkan dengan gagasan besar dalam kajian ini.

\section{HASIL DAN PEMBAHASAN}

\section{Islam dan Umat Islam}

Orang Islam manapun jika ditanya "apakah Islam ?", akan menjawab bahwa Islam adalah agama paling benar dan paling sempurna. Ajarannya lengkap dan serba meliputi. Tidak ada satu hal bahkan yang terkecil sekalipun yang luput dari pengaturan Islam. Jika ditanya "apakah umat Islam ?", akan dijawab bahwa umat Islam adalah umat terbaik di muka bumi, segala kebaikan ada padanya. Demikianlah Islam dipersepsikan sebagai agama terunggul melebihi agama lainnya dan 
umat Islam dipersepsikan sebagai umat terbaik melebihi umat lainnya. Namun kenyataan menunjukkan sebaliknya. Dunia Islam saat ini adalah dunia yang paling terpuruk, lengkap dengan kemiskinan, keterbelakangan, kebodohan, konflik berkepanjangan, perpecahan, dijajah secara politik-ekonomi-sains-kebudayaan oleh negara-negara kuat. Yang tertinggal pada umat Islam umumnya adalah keyakinan tanpa kenyataan. Yakin terhadap segala potensi keunggulan Islam dan umatnya namun tidak memiliki kemampuan merealisasikan hal itu dalam dunia empiris.

Cendikiawan muslim Ziauddin Sardar mengemukakan kritik pedasnya pada tokoh-tokoh yang dianggap sebagai ulama dunia Islam dan sering mempromosikan Islam sebagai sistem ajaran terunggul namun tidak mampu memberikan metode untuk mengaplikasikan ajaran Islam :

Perhatikanlah dalam tulisan-tulisan mereka yang monumental, baik Maulana Maududi maupun Sayyid Quthb tidak memasukkan diskusi tentang epistemologi dan ilmu pengetahuan, teknologi dan lingkungan, organisasi dan pembangunan -tema-tema hangat- yang menantang masyarakat muslim maupun masyarakat Barat dewasa ini. Lebih jauh, gambaran tentang "jalan hidup Islami” yang dibuat oleh para penulis ini tak lebih dari jalan hidup yang centang perenang dan tertutup. Sementara di satu sisi Islam ditampilkan sebagai jalan hidup yang lengkap, namun di sisi lain berbagai aspek kehidupan manusia yang meliputi aktivitas ekonomi, perilaku politik dan perkembangan pendidikan justeru dipisahkan seolah-olah tidak terkait satu-sama lain. Dalam karya Maulana Maududi maupun Sayyid Quthb, kita tidak menemukan metodologi yang integral dan interdisipliner. Akibatnya walaupun berulang-ulang ditekankan bahwa Islam 'merupakan jalan hidup lengkap", tetapi tak sedikitpun ia ditampilkan sebagai pandangan dunia yang integral dan holistik (Sardar, 2005).

Maulana Maududi (Abu al-'Ala Maududi) adalah ulama Pakistan pendiri organisasi Jami'at Islami dengan pengikut dalam jumlah sangat besar. Pemikirannya sangat berpengaruh pada masamasa awal terbentuknya negara Islam Pakistan. Sayyid Quthb adalah ulama Mesir yang juga sangat berpengaruh. Organisasinya yaitu Ikhwanul Muslimin menyebar keseluruh dunia dengan jumlah pengikut yang juga sangat besar. Keduanya adalah ahli hukum Islam. Keduanya sangat memahami sisi keunggulan Islam. Namun keduanya pasti akan kehabisan kata-kata jika ditanya tentang bagaimana metode memindahkan segala keunggulan Islam yang diinformasikan oleh kitab suci ke dunia nyata, mereka hanya memahami sisi normatif agama dan tidak memiliki metode untuk mengaplikasikannya. Akibatnya Islam terlihat bagaikan mata uang yang hanya memiliki satu sisi yaitu sisi normatif saja tanpa sisi aplikatif.

Demikian pula halnya di Indonesia, meski disadari bahwa "nilai-nilai Qur'ani secara garis besar adalah nilai kebenaran dan nilai moral, kedua nilai itu akan memacu manusia dalam membina kehidupan dan penghidupannya" (Al-Munawar, 2005). Kemudian meski pula disadari bahwa :

Sesuai perkembangan masyarakat yang semakin dinamis sebagai akibat kemajuan ilmu dan teknologi, terutama teknologi informasi, maka aktualisasi nilai-nilai al-Qur'an menjadi sangat penting. Karena tanpa aktualisasi kitab suci ini umat Islam akan menghadapi kendala dalam upaya internalisasi nilai-nilai Qur'ani sebagai upaya pembentukan pribadi umat yang beriman, bertakwa, berakhlak mulia, cerdas, maju dan madiri (Al-Munawar, 2005). 
Kemudian juga lebih disadari bahwa "sesuatu yg harus diperjuangkan dalam konteks dinamika sosial saat ini adalah mengusahakan agar nilai-nilai al-qur'an tetap aktual dalam kehidupan manusia. Sebab pada akhirnya, "aktualisasi nilai nilai al-qur'an terpulang kepada manusia itu sendiri” (Al-Munawar, 2005). Namun solusi yang ditawarkan hanya bersifat normatif tanpa wujud konkrit.

Pembinaan Iman, takwa dan akhlak mulia serta pembudayaannya pada dasarnya meliputi pembinaan tentang : keyakinan, sikap, perilaku dan akhlak mulia serta nilai-nilai luhur budaya bangsa. Semua aspek tersebut dapat berkembang apabila ada pemahaman, wawasan keagamaan dan budaya yang diperoleh dari proses alih pengetahuan, serta internasilasi nilai-nilai qur'ani dan budaya yang diperoleh dari proses alih nilai. Dalam lingkungan keluarga dan masyarakat proses alih nilai berlangsung secara lebih berkesinambungan sehingga interaksi terjadi secara efektif dibandingkan dengan yang terjadi di dalam kelas. Disamping faktor pembiasaan dan keteladanan, pembinaan iman, taqwa dan akhlak mulia serta pembudayaan dalam keluarga, juga lebih dapat berhasil karena adanya penghayatan terhadap nilai-nilai al-qur'an yang melahirkan keyakinan, sikap, perilaku dan akhlak mulia (Al-Munawar, 2005).

Pada umumnya kalimat yang disampaikan dan ditawarkan sebagai solusi adalah demikian. Namun yang dibutuhkan bukan sekedar kalimat tetapi hendaknya dapat ditunjukkan realisasi konkrit dari proses alih nilai dan atau pewarisan nilai itu seperti apa. Karena nilai yang diwariskan harus hidup dalam bentuk konkrit. Nilai yang tidak dapat diwujudkan dalam bentuk konkrit adalah nilai yang mati, nilai yang sudah menjadi fossil di museum purbakala, indah dipandang indah dikenang namun tidak memiliki fungsi dalam realitas kehidupan. Penyebabnya adalah bahwa kebanyakan para ahli hukum Islam hanya menguasai disiplin ilmu hukum Islam saja tanpa menguasi disiplin ilmu lainnya terutama ilmu Politik. Sehingga informasi dan wawasan tentang berbagai aspek kehidupan yang terbatas melahirkan kesenjangan antara nilai ajaran Islam dan aplikasinya di dunia empiris atau terputuslah antara teori dan prakteknya.

Keterbatasan informasi dan wawasan tentang berbagai aspek kehidupan terjadi pada level intelektual (ulama) juga merambat secara lebih luas lagi pada masyarakat (umat). Nilai-nilai alQur'an (agama) kehilangan peran di dalam masyarakat. Ketidakmampuan mengaktualisasikan nilai-nilai agama di dalam masyarakat telah menyebabkan hampir segala pikiran,sikap dan perilaku masyarakat tidak memiliki landasan nilai yang bersumber pada ajaran agama sebagaimana yang sewajibnya.

Namun demikian, keyakinan terhadap ajaran agama dan keinginan untuk menjalankannya tetap besar. Tetapi hal itu justeru kemudian melahirkan masalah baru yang berupa sebagai pertentangan antara ajaran agama dengan realitas kehidupan. Sebagian yang tidak begitu peduli dengan masalah ini mensikapinya dengan acuh. Tetapi sebagian yang memiliki kepedulian yang besar justru meresponnya dengan berlebihan. Ketidakmampuan umat dalam merespon berbagai realitas dengan cerdas muncul dalam bentuk sikap radikal dan teror. Persoalan-persoalan ini memperlihatkan demikian pentingnya umat Islam dalam hal ini para ahli hukum Islam terlibat 
langsung dalam proses perumusan kebijakan publik sebagai sarana untuk mengaplikasikan nilainilai ajaran agama atau syariah secara aktual.

\section{Tujuan Islam}

Islam adalah nama dari sebuah sistem nilai yang merupakan pedoman kehidupan. Pedoman tersebut berada di dalam al-Qur'an. Manusia yang mengakuinya sebagai pedoman hidupnya disebut dengan muslim atau orang beragama Islam. Tujuan manusia beragama Islam adalah untuk mewujudkan pola kehidupan yang terbaik didunia empiris. Yaitu kehidupan yang sesuai dengan fitrah kemanusiaan (Nataatmadja, 1985). Al-Qur'an adalah suatu ajaran yang terutama dimaksudkan untuk menghasilkan sikap moral yang benar dalam setiap perbuatan manusia. Perbuatan yang benar secara moral dalam hal apapun disebut sebagai ibadah (Rahman, 1992). Sebagaimana firman Allah dalam surah adz-Dzariyat (51) : 56 berikut :

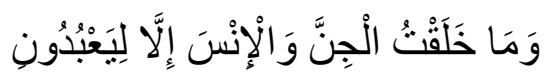

Dan aku tidak menciptakan jin dan manusia melainkan supaya mereka mengabdi kepadaKu.

Dengan demikian Islam adalah sistem kehidupan yang bersifat aktif karena ia menuntut penganutnya untuk tidak pernah berhenti berjuang mengaktualkan nilai-nilai Islam dalam kehidupan nyata (empiris). Islam tidak akan ada gunanya jika tidak diaktualisasikan di dunia empiris. Maka melakukan perjuangan mengaktualisasikan nilai-nilai Islam di dunia empiris adalah kewajiban tiada henti (Nataatmadja, 1985).

Demikian pula ditegaskan oleh al-Faruqi bahwa ber-Islam atau ber-Tauhid bukanlah sekedar mengakui bahwa Tuhan itu satu namun lebih dari itu yaitu meliputi persoalan bagaimana Islam itu diaplikasikan untuk membangun sebuah kehidupan dunia yang mensejahterakan seluruh penduduk bumi. Tauhid bukanlah sekedar kalimat bahwa "Tuhan itu satu" namun lebih dari itu Tauhid adalah pandangan yang menyeluruh dan satu padu mengenai realitas, kebenaran, dunia, ruang dan waktu. Orang bertauhid adalah orang yang hidupnya disesuaikan kepada pola Ilahiah. Pikiran, sikap, perbuatan dan apa yang dilaksanakan dalam hidupnya adalah kehendak Ilahiah. Orang bertauhid adalah orang yang kehidupannya memiliki gaya tunggal, bentuk yang integral, yang pikiran, sikap, hingga perbuatan serta apa yang dilaksanakan dalam hidupnya adalah satu kesatuan. Inilah yang disebut Islam (Al-Faruqi, 2003), dan Fazlur Rahman menegaskan bahwa segala upaya untuk mewujudkan Islam dalam kehidupan nyata disebut ibadah (Rahman, 1992).

Jika Islam hanya dianggap sebagai konsep belaka tanpa ada usaha mewujudkannya maka seorang muslim tidak akan mendapatkan kehidupan dan pengalaman agamawi. Hal ini analog dengan orang yang menghafal buku teks ekonomi tetapi tidak pernah mengalami praktek ekonomi di dunia nyata. Orang seperti itu pasti tidak memperoleh manfaat dari ilmunya dan terkutuk sebagai manusia yang berhasil menipu dirinya (Nataatmadja, 1985). 
Islam tidaknya seseorang atau iman tidaknya seseorang tidak dapat dikatakan sudah muslim atau mukmin hanya karena sekedar hapal ayat-ayat suci saja atau hanya mengenali al-Qur'ansaja. Sebagaimana kita tidak dapat mengatakan bahwa seekor monyet sudah beragama hanya karena mampu menirukan gerak ritual orang sembahyang atau sebuah robot tidak dapat dikatakan beriman hanya karena didalam memorinya tersimpan file tentang agama yang lengkap tanpa kekeliruan sedikitpun. Ukuran keimanan adalah sejauh mana kita mampu berjuang secara benar dalam melaksanakan syariat agama di dunia empiris (Nataatmadja, 1985).

Dengan demikian dapat dipahami bahwa nilai-nilai al-Qur'an yang selalu aktual adalah kebutuhan manusia. Dan aktifitas mengaktualkan nilai-nilai itu secara terus menerus adalah upaya sungguh-sungguh sebagai respon terhadap segala permasalahan baru yang terus-menerus muncul. Sehingga upaya sekecil apapun untuk menghentikan aktualisasi nilai-nilai al-Qur'an adalah penghianatan kepada al-Qur'an itu sendiri (Rahman, 1992).

Islam memiliki dua sisi yaitu sisi syariat dan sisi hakikat atau dalam istilah lain bentuk formal dan bentuk substansi. Banyak orang keliru dalam memahami ajaran Islam karena tidak mampu membedakan kedua bentuk tersebut (Nataatmadja, 2013). Sehingga banyak sekali yang beranggapan bahwa hukum-hukum yang mengatur hubungan antar manusia dipandang harus dijalankan apa adanya seperti yang berlaku dijaman Nabi. Kita lupa bahwa hubungan antara manusia dengan manusia dalam satu masyarakat bersifat kondisional kecuali hubungan yang bersifat terkait langsung dengan sakralitas seperti perkawinan (Nataatmadja, 1985). Rahman (1984) mengemukakan, adalah sangat kekanak-kanakan apabila kita menganggap bahwa al-Qur'an dan Sunnah hanya berbicara mengenai kehidupan aktual nabi muhammad di zamannya saja tanta ada kaitannya dengan zaman lainnya.

Akibatnya "ajaran Islam sebagai pedoman kehidupan terpojok menjadi ritual menyembah Tuhan belaka" (Nataatmadja, 1984), dan hanya berbicara tentang urusan alam baka saja yang tidak berhubungan sama sekali dengan dunia empiris (Nataatmadja, 1982). Padahal Islam mengajarkan bagaimana cara berjuang untuk memperoleh kedudukan disisi Allah bukan sesudah kita mati melainkan pada waktu kita hidup di bumi (Nataatmadja, 2007).

Akibat kekeliruan itulah kaum muslim menjadi tertinggal. Islam identik dengan bentuk formalnya saja. Maka pemikiran dan kreatifitas mewujudkan substansi nilai Islam di dunia empiris terhenti. Pada saat pikiran telah dibunuh maka Islam menjadi tidak berfungsi dalam merespon realitas yang terus berkembang. Hal ini memperlihatkan bahwa sebenarnya umat Islam tidak mengenal ajaran Islam. Sejarah memberikan bukti yang sangat gamblang bagaimana kaum muslimin sang pionir pencipta pembaharuan berubah menjadi kaum terjajah di buntut peradaban (Nataatmadja, 2007).

Hal inilah yang menjadi penyebab mengapa kaum muslim mengalami musibah berkepanjangan.Kekeliruan tersebut menjadikan kaum muslim sang pemilik al-Qur'an pedoman yang sempurna bisa dikalahkan dengan mudah oleh kaum kafir seperti Belanda, Jepang dan Israel (Nataatmadja, 1985). Akibatnya pula kaum muslim mengalami kekalahan dan keterbelakangan dalam segala bidang. Kekalahan dan keterbelakangan ini direspon oleh sebagian kaum muslim 
dengan melakukan berbagai tindakan teror sebagai bentuk ketidakmampuan dalam memberikan respon terhadap realitas secara cerdas (Nataatmadja, 1985). Berbagai kasus kekerasan atas nama agama yang terjadi di Indonesia memberikan bukti bagaimana sebagian umat Islam tidak mampu memberikan respon secara cerdas ketika berhadapan dengan realitas yang tidak disukai atau tidak mampu dihadapi kemudian memilih penyelesaian menggunakan kekerasan.

\section{Syariah dan Fikih}

Jalan keluar dari permasalahan ini adalah merubah cara berpikir kaum muslimin mengenai Islam. Dari cara berpikir bahwa Islam adalah seonggok dogma menjadi cara berpikir bahwa Islam adalah landasan cara berpikir dan cara berperilaku yang substansi nilainya harus terus menerus diperjuangkan diaktualisaikan wujud nyatanya dalam kehidupan (Nataatmadja, 1983). Tujuan dari penerapan nilai-nilai Islam di dunia empiris adalah terbagunnya sebuah tatanan kehidupan yang sesuai dengan fitrah manusia itu sendiri yaitu hidup bahagia yang di dalamnya ada keadilan dan kesejahteraan (Nataatmadja 1985). Terwujudnya kehidupan yang demikian akan terasa dampaknya bukan oleh kaum muslimin saja tapi juga oleh seluruh penduduk bumi. Itulah yang dimaksud dengan Islam sebagai rahmatan lil 'âlamîn (Nataatmadja, 1984). Sebagaimana diungkapkan oleh Idzomiddin (2013) :

Misi utama yang di syariatkan hukum Islam adalah untuk kemaslahatan (kesejahteraan) umat manusia pada umumnya dan umat Islam pada khususnya. Karena itu kecenderungan yang dominan dari hukum Islam adalah komunal. Komunal berbeda dengan sosialistik. Komunal memiliki pengertian yang lebih luas yang mencakup segi materi dan segi-segi lain yang meliputi seluruh hak dan kewajiban, sedangkan sosialistik mempunyai pengertian khusus yang terbatas pada materi. Kecenderungan hukum Islam yang komunal ini dapat terlihat dengan jelas baik dalam ibadah maupun muamalah. Semua aturan hukum Islam dalam kedua bidang ini bertujuan mendidik Individu untuk mewujudkan kesejahteraan dirinya dan kesejahteraan masyarakat secara keseluruhan.

Tujuan dari syariah (maqasid asy-syariah) adalah maslahat (Romli, 2009). Maslahat berarti kebaikan menyeluruh bagi msyararakat atau kesejahteraan dan mengindarkan masyarakat dari kerusakan dan kehancuran. Selama masyarakat eksis maka masyarakat akan membutuhkan kemaslahatan dan harus dilindungi dari kemudharatan. Maka ditengah kehidupan masyarakat yang dinamis dan terus berubah tersebut, produk-produk hukum baru sebagai dasar bagi masyarakat untuk berpikir dan berperilaku untuk mencapai maslahat dan menghindarkan mudharat mutlak dibutuhkan dan harus terus ada tanpa boleh berhenti (Romli, 2009). Disinilah fungsi aktualisasi agama. Agama harus terus menerus mampu menjawab berbagai persoalan-persoalan baru yang belum pernah ada pada masa Rasul saw hidup atau di masa awal para ahli hukum hidup. Rumusan hukum-hukum atau fikih-fikih baru yang ditujukan untuk menjawab persoalan-persoalan baru disebut juga sebagai fikih kontemporer (Romli, 2009).

Kegiatan yang sungguh-sungguh dan terus menerus mengaktualkan nilai-nilai syariat, dengan memproduksi hukum-hukum baru atau fikih-fikih kontemporer yang berkaitan dengan 
segala persoalan baru, yang terus menerus timbul di masyarakat disebut dengan ijtihad. Ijtihad tidak boleh terhenti. Terhentinya ijtihad akan berakibat dua hal. Pertama terhentinya kegiatan berpikir. Kedua terhentinya produksi hukum-hukum baru, ketiga agama menjadi mandeg, membeku kehilangan fungsi dan keempat akan lahir masyarakat tanpa arah, tanpa pikiran sikap dan perilaku yang jelas karena hidupnya tidak memiliki standar (Hasan, 1984).

Pihak yang paling memikili kompetensi untuk memproduksi hukum-hukum baru atau fikihfikih kontemporer adalah para ahli Hukum Islam. Baik mereka yang bekerja resmi di lembaga pemerintah, lembaga swadaya masyarakat, maupun sebagai tokoh non formal sebagai Da'i. Disinilah pentingnya penguasaan lintas disiplin oleh satu pribadi. Fikih-fikih baru ini tentu saja ditetapkan secara bersama oleh para ahli hukum, kegiatan ini disebut ijma'. Namun ide awal mestilah muncul dari setiap pribadi yang menguasai suatu disiplin ilmu tertentu disamping disiplin ilmu dasar yaitu hukum Islam.

Sebagai contoh 1200 tahun lalu (200 tahun sesudah Nabi wafat), para ahli hukum Islam telah merumuskan standar keabsahan air wudlu, sebagai respon terhadap perkembangan dan perubahan kondisi lingkungan hidup masa itu yaitu : tidak mengandung najis, tidak berbau dan dengan volume minimal 2 kullah. Selama 1200 tahun pula standar ini sama sekali tidak mengalami perubahan. Standar tersebut demikian sederhana, karena standar itu dibuat pada masa dimana bumi belum mengenal penggunaan zat kimia secara massif dan bumi juga belum tercemar oleh radioaktif serta belum tercemar bakteri-bakteri mengerikan. Kemudian tentu saja standar itu sudah sangat kadaluarsa bagi kita yang hidup di zaman serba zat kimia, serba bakteri dan serba radiasi saat ini. Namun dikarenakan para ahli hukum Islam tidak menguasai disiplin ilmu kimia, biologi dan atau fisika maka tidak terpikirkan sedikitpun bahwa hal-hal itu ada disekitar kita dan mengancam kemaslahatan hidup masyarakat. Maka hingga hari ini belum pernah diproduksi fikih-fikih baru yang berhubungan dengan standar kualitas air. Akibatnya bukan hanya sekedar standar air sehat yang tidak jelas, lebih jauh lagi masyarakat tidak memiliki standar sikap dan perilaku terhadap air. Baik air tanah, air sumur, air danau, air sungai, air hujan, air laut dan air beku di kutub.

Jika para ahli hukum Islam memproduksi hukum-hukum baru yang aktual untuk zaman ini, maka akan jelas bagi masyarakat bahwa penggunaan air yang tercemar untuk segala keperluan hidup adalah haram. Lebih jauh lagi, masyarakat akan memiliki standar sikap dan perilaku bahwa segala perbuatan yang mengakibatkan pencemaran air adalah dosa, karena hal itu adalah pelanggaran terhadap hukum agama. Dengan demikian para pembuang sampah ke sungai, para pembuang zat kimia ke sumber air, para penyebab menyebarnya radiasi adalah para pendosa, melanggar hukum agama sekaligus hukum negara.

\section{Kebijakan Publik}


Dalam konteks kehidupan bernegara, nilai-nilai yang ingin di aplikasikan dalam kehidupan masyarakat dapat diterjemahkan secara legal melalui kebijakan politik. Dengan demikian Masyarakat dapat hidup sesuai dengan nilai-nilai yang diharapkannya. Siapapun yang ingin memperjuangkan sebuah nilai keyakinan menjadi tatanan aplikatif maka mereka dapat memperjuangkannya dengan cara turut berperan aktif dalam proses perumusan kebijakan publik. Semakin tinggi peran yang dapat dilakukan maka semakin luas pula nilai-nilai yang dapat diperjuangkan menjadi kebijakan publik dan sebaliknya.

Pada bagian selanjutnya penulis akan melengkapi tulisan ini dengan beberapa hal yang terkait dengan kebijakan publik yaitu pengertian kebijakan publik, ruang publik, fungsi kebijakan publik dan proses kebijakan publik.

Parsons (2008), mengutip pengertian kebijakan publik menurut beberapa ahli sebagai berikut, Dewey (1927) mengemukakan bahwa kebijakan publik adalah persoalan "publik dan problem-problemnya". Heidenheimer (1990) mengemukakan bahwa kebijakan publik adalah "bagaimana isu-isu dan persoalan - persoalan tersebut disusun dan didefinisikan, dan bagaimana kesemuanya itu diletakkan dalam agenda kebijakan dan agenda politik". Kemudian Dye (1976) mengemukakan bahwa kebijakan publik adalah "apa yang dilakukan oleh pemerintah, mengapa pemerintah mengambil tindakan tersebut dan apa akibat dari tindakan tersebut".

Dari beberapa definisi yang dikemukakan oleh Parsons dapat disimpulkan bahwa kebijakan publik adalah apapun yang dilakukan oleh pemerintah yang berkaitan dengan urusan publik. Urusan publik diistilahkan juga dengan ruang publik. Parsons (2008: 3) menyatakan, ruang publik setidaknya meliputi 13 (tigabelas) jenis urusan yaitu :1. Kepentingan Publik (public interest), 2. Opini Publik (public opinion), 3.Barang-barang publik (public goods), 4.Hukum publik (public law), 5.Sektor publik (public sector), 6. Kesehatan publik (public health), 7.Transportasi publik (public transpot), 8.Pendidikan publik (public education), 9. Siaran Layanan publik (public service boadcasting), 10. Akuntabilitas publik (public accountability), 11. Toilet publik (public toilets), 12. Ketertiban umum (public order), 13.Utang publik (public debt)

Dari ketigabelas urusan publik atau ruang publik tesebut maka dapat kita lihat bahwa kebijakan publik meliputi seluruh urusan hidup masyarakat. Dengan demikian peran serta dalam perumusan kebijakan publik akan sangat menentukan bagaimana keseluruhan aspek kehidupan sebuah masyarakat ditata dan dikelola.

Dengan melakukan pengurusan terhadap seluruh urusan hidup masyarakat, maka pemerintah telah melakukan fungsi dari kebijakan publik yaitu pelayanan publik atau publik servis. Publik servis adalah tugas utama pemerintah yang diimplementasikan dalam bentuk kebijakan.

Parsons (2008) mengemukakan bahwa sebuah kebijakan publik setidaknya diawali dari proses melihat fakta atau permasalahan aktual di masyarakat, kemudian merumuskannya menjadi pemasalahan publik dan lalu membentuknya menjadi opini publik. Opini publik yang telah terbentuk apalagi tebentuk secara luas dengan sendirinya akan menjadi perhatian, baik oleh publik sendiri maupun terutama oleh pemerintah. Dengan demikian akan lahir kebutuhan untuk menyelesaikan permasalahan publik tesebut. Dengan berbagai instrumen yang dapat dilakukan 
seperti hasil penelitian, kajian para ahli dan usulan kepada legislatif dan eksekutif maka akan lahirlah sebuah kebijakan publik.

\section{Peluang Peran Serta Para Ahli Hukum Islam Dalam Perumusan Kebijakan Publik Di Indonesia}

Sebagaimana telah diungkapkan pada bagian latar belakang, bahwa umat Islam tidak boleh menjauhi dunia politik. Dari politiklah diproduksi berbagai kebijakan publik yang diperuntukkan menata dan mengelola segala urusan hidup warga negara. Dalam konteks kehidupan berbangsa dan bernegara Indonesia, terbuka ruang yang cukup luas bagi umat Islam untuk mewujudkan syariah menjadi kebijakan publik. Yaitu dengan cara turut memasukkan nilai-nilai yang terkandung di dalam syariah ke dalam proses perumusan kebijakan publik, tanpa memaksakan bentuk-bentuk konkrit yang pernah ada di masa lalu.

Berdasarkan penjelasan Parsons mengenai proses perumusan kebijakan publik, maka sebenarnya para ahli hukum Islam tidak perlu turun gelanggang menjadi aktor-aktor politik yang tampil dalam pencalonan diri sebagai kepala negara, kepala daerah, DPD maupun legislatif. Mereka cukup melakukan peran aktif dalam proses perumusan kebijakan publik saja.

Adapun proses yang dimaksudkan oleh Parsons yang dapat dilakukan oleh para ahli hukum Islam adalah : pertama melihat fakta atau permasalahan aktual di masyarakat, yang kedua merumuskannya menjadi pemasalahan public, ketiga membentuknya menjadi opini public, keempat memposisikan opini publik menjadi perhatian publik dan pemerintah, kelima akan lahir kebutuhan penyelesaian masalah public dan yang keenam dengan berbagai instrumen seperti hasil penelitian, kajian ahli dan usulan kepada legislatif dan eksekutif serta persetujuan keduanya akan lahirlah sebuah kebijakan publik.

Meski ke-enam langkah ini tampak sederhana namun jika dijalani, proses tersebut merupakan perjuangan panjang, rumit dan melelahkan. Namun menurut penulis justeru inilah jihad sosial politik yang sesungguhnya. Umat Islam tidak perlu mengangkat senjata untuk menguasai dunia politik dan kebijakan di Indonesia, juga tidak perlu membunuhi orang-orang kafir, tetapi dengan kekuatan intelektualitas dan daya tawar-menawar politik yang tinggi. Sebagai proses perjuangan yang melelahkan tentunya yang saat ini dibutuhkan oleh umat Islam adalah para ahli hukum Islam (ulama) yang siap berjuang dengan tulus dan tanpa pamrih seumur hidupnya.

\section{Kebijakan Publik Bersumber dari Syariah}

Berikut beberapa contoh kebijakan publik yang seharusnya sudah diproduksi sejak lama sebagai respon atau aktualisasi nilai-nilai syariah dalam kehidupan masyarakat yang dinamis dan senantiasa terus-menerus berkembang. A. Kebijakan Bidang Penanggulangan Bencana Alam di Kaki Gunung Berapi, Daerah Rawan Longsor dan Rawan Gempa serta Tsunami. Selain itu kebijakan dalam bencana alam di kaki gunung berapi karena Indonesia dikenal sebagai negara The Ring of Fire, terdapat 207 gunung api aktif di Indonesia dengan 37juta jiwa tinggal di kaki gunung 
berapi tersebut. 37juta jiwa ini hidup dalam resiko kematian yang tinggi yaitu resiko tersapu awan panas, lahar panas, hujan batu, hujan lahar dingin dan sebagainya. Persoalan sedemikian besar ini luput dari perhatian para ahli hukum Islam. Seharusnya para ahli Hukum Islam sejaka lama turut berperan menetapkan kebijakan larangan bertempat tinggal dalam radius minimal $3 \mathrm{~km}$ dari puncak gunung berapi. Karena dengan sengaja membahayakan keselamatan jiwa dan harta tergolong sebagai usaha bunuh diri dan hal itu adalah dosa besar.

Selain itu pemerintah juga harus merumuskan beberapa hal kebijakan strategis dalam penanganan bencana alam dibeberapa daerah rawan gempa serta tsunami serta memperhatikan sanitasi, kesehatan lingkungan, standar kehalalan makanan, kebijakan dalam penggunaan teknologi informasi, hokum ekonomi, mengatur persoalan peribadatan dan lain sebagainya yang menyangkut hajat masyarakat umum.

Demikianlah setidaknya terdapat beberapa kebijakan publik dimana para ahli hukum Islam dapat turut serta secara aktif merumuskan kebijakan publiknya, sebagai respon para ahli hukum Islam atas segala dinamika masyarakat dan sebagai bentuk aktualisasi nilai-nilai syariah dalam kehidupan sehari-hari. Kebijakan publik ini belum juga tersentuh oleh para ahli hukum dikarenakan kurangnya inisiatif yang ada tidak memungkinkan mereka berpikir lebih jauh untuk menanggapi hal-hal yang seharusnya telah ditanggapi sejak lama. Terlihat pula bagaimana pentingnya penguasaan lintas disiplin bagi para ahli hukum Islam. Kemampuan mereka mengaktualisasikan nilai-nilai agama akan membuat agama menjadi dinamis dan hidup. Sebaliknya ketidakmampuan mereka mengaktualisasikan nilai-nilai agama dalam kehidupan sehari-hari akan membuat agama menjadi kehilangan peran dan fungsinya.

\section{KESIMPULAN}

Agama Islam adalah sumber nilai yang harus senantiasa diaktualkan dalam kehidupan sehari hari yang senantiasa dinamis dan menghasilkan hal-hal baru yang belum ada landasan hukumnya di masa lalu. Para sarjana hukum Islam memiliki peran yang sangat penting dalam mengaktualkan nilai-nilai ajaran Islam dalam kehidupan sehari hari. Peran tersebut berupa turut serta dalam merumuskan kebijakan-kebijakan publik bersama legislatif dan eksekutif.

Untuk mampu berperan serta dalam proses perumusan kebijakan publik maka para ahli hukum Islam harus mengembangkan wawasan keilmuannya khususnya dalam bidang politik dan kebijakan publik. Turut sertanya para ahli hukum Islam dalam proses perumusan kebijakan publik merupakan jihad sosial politik yang sesungguhnya. Untuk itu dibutuhkan pibadi-pribadi tangguh dan tulus untuk berjuang mengaplikasikan nilai-nilai syariah dalam kehidupan sehari-hari secara legal melalui peran aktif dalam perumusan kebijakan publik. 


\section{DAFTAR PUSTAKA}

Al-Faruqi, dkk. (2003). Atlas Budaya Islam, Menjelajah Khazanah Peradaban Gemilang (Edisi keempat). Penerbit Mizan, Bandung.

Al Munawar, Said Agil Husin. (2005). Aktualisasi Nilai-Nilai Qur'ani Dalam Pendidikan Islam. Penerbit Ciputat Press. Jakarta.

Dunn, William. N. (2003) Pengantar Analisis Kebijakan Publik. Gadjah Mada University Press. Yogyakarta.

Hasan, Ahmad. (1984). Pintu Ijtihad Sebelum Tertutup. Penerbit Pustaka. Bandung.

Ibrahim, Duski. (2008). Metode Penetapan Hukum Islam, Membongkar Konsep Al-Istiqra' AlMa'nawi Asy-Syatibi. Ar-Ruzz Media. Yogyakarta.

Izomiddin, Dr. MA. (2013). Pemikiran dan Filsafat Hukum Islam. Rafah Press, Palembang.

Nataatmadja, Hidayat. (1982). Krisis Global Ilmu Pengetahuan dan Penyembuhannya. Penerbit Iqra, Bandung.

--------.-. (1983). Membangun Ilmu Pengetahuan Berlandaskan Ideologi. Penerbit Iqra, Bandung.

Yogyakarta.

(1984). .Pemikiran Kearah Ekonomi Humanistik. Penerbit PLP2M,

. (1984). Ilmu Humanika. Penerbit Risalah, Bandung.

(1985). Kebangkitan Al-Islam. Penerbit Risalah, Bandung.

------------ (2007). Mukjizat Al-Qur'an v.s, Tahayul Iptek Seri-2. Penerbit Intuisi Press, Jakarta.

Lankap, Yogyakarta.

Parsons, Wayne. (2008). Publik Policy, Pengantar Teori dan Praktik Analisis Kebijakan. Penerbit Prenada Media Kencana. Jakarta.

Rahman, Fazlur. (1984). Membuka Pintu Ijtihad. Penerbit Pustaka. Bandung. . (1992). Islam. Penerbit Bumi Aksara. Jakarta.

Romli. (2009). Konsep Maslahat Dan Kedudukannya Dalam Pembinaan Tasyri'. Rafah Press. Palembang.

Sardar, Ziauddin. (2005). Kembali Ke Masa Depan, Syariat Sebagai Metodologi Pemecahan Masalah. Penerbit PT. Serambi Ilmu Semesta, Jakarta

Schuon, Frithjof. (1993). Islam dan Filsafat Perenial. Penerbit Mizan. Bandung. 